\title{
The Legal Concept of Public Private Partnership (PPP) and its Limited Scope in Nigeria
}

\author{
Faruk Sani \\ Faruk Sani Chambers, Nigeria
}

\begin{abstract}
The paper sets out to determine the adequacy or otherwise of the definition of Public Private Partnership (PPP) in Nigeria. As a result of paucity of public funds, Nigeria introduced the concept of PPP in its public procurement strategy so as to tackle its glaring infrastructure deficit, which presently, is put at $70 \%-75 \%$ of GDP. Despite the enthusiasm of stakeholders in this respect, the fundamental challenge is the capacity, within the extant legal framework that used the term 'concession', to identify the scope, parameters and limitations of the concept in exploring available options for successful delivery of PPP projects in Nigeria. The significance of correct identification of PPP parameters for the participation of the private sector in the delivery of public infrastructure and services cannot therefore be underestimated considering Nigeria's aspiration and the role of infrastructure to economic growth and national prosperity. Using a doctrinal research methodology and a purposive sampling technique, the paper reviewed extant definitions of the concept in many PPP national jurisdictions, international organizations and relevant academic writers to conclude that the definition of PPP under section 36 of the Infrastructure Concession Regulatory Commission (ICRC) Act is inadequate. Such a definition is incapable of capacitating public authorities to explore all available PPP options in their effort to achieve Nigeria's desire for private financing of public infrastructure and services. Out of the five legal parameters identified by this paper for any standard definition of PPP, the definition under section 36 of the ICRC Act met only two parameters. It therefore recommended that the ICRC Act should be amended to be more expansive as to accommodate the different types, classifications and parameters of the PPP definitions propounded in the guidelines of many Multilateral and Development Banks (MDBs).
\end{abstract}

Keywords: PPP Contracts, Legal definitions, Infrastructure Provision, Legal Framework

\section{INTRODUCTION}

$\mathrm{P}$ ublic Private Partnership (PPP) has emerged as one of the most dynamic strategies of National and sub-National governments for the successful delivery of public infrastructure and services. More often that not, the nomenclature 'PPP' is widely being peddled by public infrastructure enthusiasts as the panacea for closing the infrastructure stock deficits of National governments. Beyond the colloquial usage of the term, every Nigeria's National plan and policy from 1986 to date, including the National Policy on PPP has adopted and used the word 'PPP'. Curiously, the dominant legislation on PPP, the Infrastructure Concession
Regulatory Commission Act (ICRC Act) ${ }^{1}$ of 2005 , did not use the word 'PPP'. Rather, and as will be seen later, it used the word 'concession', which it defined as a contractual arrangement for the construction, financing, operation and maintenance of infrastructure. This non-usage of the word 'PPP' has not however, waned the utilization of the concept as a viable option in public infrastructure procurements.

The central thrust of this paper therefore is a comprehensive understanding of the general parameters of the PPP concept with a view to determining the adequacy or otherwise of the concept under the ICRC Act. Being a doctrinal research, the paper, examines the various definitions of PPP by identified multilateral, bilateral and developmental institutions as well as those in National jurisdictions and by academic writers with the main objective of discovering common threads or features among them. This is critical because, to a large extent, they could reveal whether or not the definition of the concept in Nigeria is adequate and encompassing. To achieve its objective of understanding common PPP features that are relevant to Nigeria's legal system therefore, the paper adopts the purposive sampling technique in its selection of national jurisdictions, MDBs and academic writers for discussion. These national jurisdictions, MDBs and academic writers were purposively identified and selected for discussion in view of their attachment to the common law legal system which is same as that of Nigeria, the success they have recorded in their PPP strides, the extent of PPP literature they have either produced or facilitated, and the need to leverage on their respective experiences in the delivery of PPP projects.

The paper therefore is divided into four sections. The first section reviews the concept of PPP in Nigeria, the second section discusses the concept in the legal instruments of the selected international development institutions, the third section is on what obtains in other national jurisdiction, while the fourth section is the conclusion and recommendations.

PPP has a rich historical background that traced its origin as far back as the Roman Empire when it developed a system, based on a long-term partnership and shared risks, for the

\footnotetext{
${ }^{1}$ Infrastructure Concession Regulatory Commission (Establishment, Etc.) Act, Cap. 125A, LFN 2004.
} 
transportation of grains to the inhabitants of Rome. ${ }^{2}$ However, its evolution in Nigeria was part of the macroeconomic reform influenced by the World Bank and International Monetary Fund (IMF) in $1986^{3}$ in which the Federal Government constituted the Technical Committee on Privatization and Commercialization (TCPC) in $1988^{4}$ pursuant to the Privatization and Commercialization Act, ${ }^{5}$ whose objective was to pursue and implement the concept of private participation in public infrastructure through privatization and commercialization.

The TCPC was however succeeded by the Bureau for Public Enterprises (BPE), which had a turning point between 2002 and 2004, when it embarked upon a new model of private sector participation, the concessions. The model was used for the concession of MM2 and twenty-five NPA terminals to private operators. ${ }^{6}$ Following the promulgation of the ICRC Act ${ }^{7}$ to deepen the participation of the private sector in public infrastructure, late President Umaru Musa Yar'Adua GCFR inaugurated the Board of the Commission on $27^{\text {th }}$ November 2008 with Engr. Mansur Ahmed as its pioneer Director General. ${ }^{8}$ Although the BPE and ICRC legislation have existed side by side, the dominant PPP legislation in Nigeria is the ICRC Act, which empowers all federal ministries and agencies to grant concessions to private sector operators for the delivery and funding of public infrastructure and services. ${ }^{9}$ This is notwithstanding a recent circular of the Secretary to the Government of the Federation (SGF), which restricted ICRC to PPP regulatory functions only. ${ }^{10}$

\section{The Concept of Public Private Partnership}

\footnotetext{
${ }^{2}$ J. Leitao and E. de Morais Sarmento and J. Aleluia, The Handbook on Pubic-Private Partnerships in Developing and Emerging Economies: Perspectives of Public Policy, Entrepreneurship and Poverty (Emerald Publishing Limited, 2018), 7; <https://www.academia.edu/36179545/The_Emerald

_Handbook_of_Public_Private_Partnerships_in_Developing_and_Emerging Economies_Perspectives_on_Public_Policy_Entrepreneurship_and_Poverty> Accessed 6 August 2019.

${ }^{3}$ D O Adeyemo and Adeleke Salami, 'A Review of Privatization and Public Enterprises Reform in Nigeria', Contemporary Management Research Journal, [2008] (12) (4) 409.

${ }^{4}$ The inauguration of the Technical Committee was sequel to the promulgation of the Privatization and Commercialization Act, No. 25 of 1988.

${ }^{5}$ No. 25 of 1988 .

${ }^{6}$ F. Onuobia and O. J. Okoro, 'Nigeria', in Wereck B. and Saadi M. (eds), Public Private Partnership Law Review ( $4^{\text {th }}$ Ed., Tom Barnes 2018), 181 〈https://www.gelias.com/Newsletter_April\%202018.pdf〉. Accessed 04 October 2019.

${ }^{7}$ No. 18 of 2005; Cap. 125A, LFN 2004.

${ }^{8}$ Infrastructure Concession Regulatory Commission, History (2020) 1, $<$ https://www.icrc.gov.ng/about-icrc/> Accessed 11 ${ }^{\text {th }}$ January 2021.

${ }^{9}$ ICRC Act, s. 1.

${ }^{10}$ Circular Ref. No. SGF.50/S.37/II/749 of $14^{\text {th }}$ September 2020.
}

Like many concepts, PPP defies a universally accepted definition. ${ }^{11}$ This may not be surprising as its scope and content ${ }^{12}$ has significantly changed during its historical evolution. Consequently, slight differences are noticeable from epoch to epoch, from jurisdiction to jurisdiction, and even among bilateral, multilateral and financial development institutions. The observation of the World Bank was therefore apt that an increasing number of countries are enshrining and tailoring the definition of PPPs in their legislation to their institutional and legal peculiarities. ${ }^{13}$

As pointed out earlier, Nigeria's dominant legislative framework on PPP did not use the familiar terms of 'PPP' and 'private sector'. Rather, it adopted the nomenclature of 'concession' and 'project proponents'. In the same vein, the Privatization and Commercialization Act did not use the term 'PPP'. This may not be surprising as the Act was principally on the privatization and commercialization of public enterprises. Similarly, the notable PPP projects in Nigeria, the MMA2 and Seaports terminal transactions were all described as concessions. However, the National Policy on PPP, a subsidiary legislation that was promulgated four years after the ICRC Act, used the term PPP copiously, making stakeholders to be comfortable with the word PPP. It did not, observably, define PPP. The ICRC Act, ${ }^{14}$ on the other hand, defined concession as:

A contractual arrangement whereby the project proponent or contractor undertakes the construction, including financing of any infrastructure, facility and the operation and maintenance thereof and shall include the supply of any equipment and machinery for any infrastructure.

In order to fully understand the concept of PPP under the ICRC Act, reference must be done to section 7(2)(b), which put the obligation of maintenance and repairs on every private entity when it stated that 'the project proponent or contractor shall ... undertake the maintenance or repairs of the infrastructure or facility during the subsistence of the contract. ${ }^{15}$ Although the scope of private sector participation is yet to receive any judicial pronouncement, it is obvious that this definition, within the context of the non-binding PPP guidelines of MDBs, as will be seen later, is inadequate.

\footnotetext{
${ }^{11}$ African Development Bank Group, Evaluation of the Bank's Utilization of the Public Private Partnership Mechanism (2006 - 2016): Inception Report Volume 1, Main Report [03 April 2017], 9. $<$ http://idev.afdb.org/sites/default/files/documents/files/PPP-

Inception\%20Report\%20Vol\%201\%20Main \%20Report.pdf>. Accessed 04 January 2020.

${ }^{12}$ The problem of definition will manifest if it is defined from its delivery mode, for instance, the additional scope of design in DBOT will change the definition of a BOT in PPPs. So also are concessions, Affermage, amortization, etc.

${ }^{13}$ PPP Legal Research Centre, World Bank, What are Public Private Partnerships? $\quad 1 \quad<$ https://ppp.worldbank.org/public-privatepartnership/overview/what-are-public-private-partnerships>. Accessed 03 January 2020.

${ }^{14}$ ICRC Act, s. 36

${ }^{15}$ Ibid, s. 7(2)(b).
} 
An examination of the definitions in many legal instruments of public institutions and National jurisdictions will show that PPP is considered from different perspectives that include transactional where it is seen as a pure transaction between two entities; operational where execution of project is being emphasized; commercial where return on investment is being prioritized; and transfer of public responsibility when performance of governmental functions is considered as the centre of the arrangement. Such perspectives make it difficult to categorize the discipline of PPP, i.e. whether it is a transaction arrangement, an engineering project, or a financial mechanism for private sector delivery of public infrastructure. In all the arrangements however, the central focus in the definition of PPP is the private sector financing of public infrastructure and services. The various definitions of the concept put forward by multilateral development institutions, national jurisdictions and academic writers, which though of persuasive effects, would assist greatly in understanding the dimensions and manifestations of PPP as well as the adequacy or otherwise of the Nigerian PPP concept.

\section{PPP Concept in Legal Instruments of International Development Institutions}

All the international development institutions and multilateral development banks (MDBs) have recognized PPP as a veritable catalyst for economic growth and national prosperity. These international institutions and MDBs like the United Nations Commission on International Trade Law (UNCITRAL), the World Bank, the International Monetary Fund (IMF), the European Bank for Reconstruction and Development (EBRD), the Organization of Economic Cooperation and Development (OECD) and other regional development banks such as the Asian Development Bank (ADB), the African Development Bank (AfDB), the European Investment Bank (EIB), etc. provide loans and grants in the respective countries of their cooperation in order to promote social and economic development. It was in this respect that they prepared guidelines or commissioned reports on PPP, which could assist in PPP implementation as well as provide objective criteria to determine funding eligibility and performance assessment. ${ }^{16}$ These guidelines and reports contain definitions of PPP, which are meant to provide guidance on PPP legislation, albeit in a non-binding manner, for these countries. Although Nigeria has always successfully collaborated with MDBs in its PPP projects, ${ }^{17}$ it is obvious that such collaboration could be more beneficial if its system

\footnotetext{
${ }^{16}$ For example, after analyzing the declining investments in developing markets and the growing importance of MDBs role in private sector participation in public infrastructure delivery, EBRD declared that it was particularly keen to expand the level of PPP activity in the regions of its operations. EBRD, Public-private Partnerships (PPPs) 3 <https://www.ebrd.com/infrastructure/infrastructurePPPs.com>. Accessed 04 January 2020.

${ }^{17}$ The World Bank assisted Nigeria in its seaport terminal concessions while the AfDB provided the necessary financial structure that enabled Lekki Concession Company limited to achieve financial close within record time.
}

is more transparent, predictable and in line with established guidelines.

The World Bank defined PPP as a long-term contract between a private party and a government entity to provide a public asset or service, to ensure that the private party bears significant risk and management responsibility, and to link remuneration to performance. ${ }^{18}$

UNCITRAL published the Legislative Guide on Privately Funded Infrastructure Projects in 2000 and the Model Provisions on Privately Funded Infrastructure Projects in $2003,{ }^{19}$ whose objective was to assist countries in the establishment of a legal framework favourable to private investments in public infrastructure. ${ }^{20}$ The Guide did not contain a definition of PPP. It only contained that of its variant, concession. Under Model Provision 2(e) of the Resolution adopted at the $72^{\text {nd }}$ plenary meeting of the United Nations General Assembly on $9^{\text {th }}$ December 2003, 'concession contract' was defined as mutually binding agreement or agreements between the contracting authority and the concessionaire that set forth the terms and conditions for the implementation of an infrastructure project. ${ }^{21}$

The European Commission, through the European Investment Bank, recognized PPP as a long-term contractual arrangement for the provision of public assets and related services in exchange for performance-based payments, which is linked to the availability and usage of assets or the delivery of related services. ${ }^{22}$ The IMF, while observing that there was no clear agreement on what constitutes a PPP, ${ }^{23}$ endorsed the definition of the European Commission that PPP is a transfer to the private sector of investment projects that are traditionally executed or financed by the public sector. ${ }^{24}$

The European Bank for Reconstruction and Development (EBRD) developed a set of ten core principles to guide countries in the European Union (EU) to understand and promulgate modern concession laws. ${ }^{25}$ It defined concession as 'a long-term contractual relationship between a state or a

\footnotetext{
${ }^{18}$ Ibid, World Bank, PPP Legal Research Centre, What are Public Private Partnerships? $\quad 1 \quad<$ https://ppp.worldbank.org/public-privatepartnership/overview/what-are-public-private-partnerships>. Accessed 03 January 2020.

19 UNCITRAL, Model Legislative Provisions on Privately Funded

<https://www.uncitral.org/pdf/english/texts/procurem/pfip/model/03-

90621_Ebook.pdf>. Accessed 02 January 2020.

${ }^{20}$ Ibid, $x i$.

${ }^{21}$ Ibid, 6 .

${ }^{22}$ The European Commission, A Guide to the Statistical Treatment of PPPs [2016] 18 <https://ec.europa. eu/eurostat/documents/1015035/7204121/epeceurostat-statistical-guide-en.pdf $>$. Accessed 04 January 2020.

${ }^{23}$ International Monetary Fund, Public Private Partnerships [2004] 6 < https://www.imf.org/external/np/ fad/2004/pifp/eng/031204.pdf>. Accessed 04 January 2020.

${ }^{24}$ The European Commission, (n. 22).

${ }^{25}$ European Bank for Reconstruction and Development, The EBRD Core Principles for a Modern Concession Law: Selection and Justification of Principles, $\quad 1 \quad<$ https://ppp.worldbank.org/public-privatepartnership/sites/ppp.worldbank.org/files/documents/Core\%20Principles\%20f or\%20Modern\%20Concession\%20Law_EN.pdf>. Accessed 04 January 2020.
} 
state owned entity (SOE) and a private sector entity whereby the latter delivers and funds public services using a capital asset and sharing the associated risks with the state or SOE' ${ }^{26}$

The Organization for Economic Cooperation and Development (OECD), in its Principles for Public Governance of Public Private Partnership, ${ }^{27}$ PPP was defined as a long term contractual arrangements between the government and a private partner whereby the latter delivers and funds public services using a capital asset and sharing the associated risks. ${ }^{28}$

In its PPP Handbook, ${ }^{29}$ the Asian Development Bank defined PPP as a contractual arrangement between the public, which it restricted to national, state, provincial or local, and private entities 'through which the skills, assets and financial resources of each of the public and private sectors are allocated in a complimentary manner, thereby sharing the risks and rewards, to seek to provide optimal service delivery and good value to citizens. ${ }^{30}$

In the Inception Report on the evaluation of the banks utilization of the public private partnership mechanism for 2006 - 2016, the African Development Bank endorsed the definition of PPP as a mechanism that involves the public and private sectors working in co-operation 'to provide infrastructure and services, and is fundamentally about bringing together the expertise of the private and public sectors and allowing each sector to do what it does best in order to deliver projects and services in the most efficient manner, ${ }^{31}$

Before the paper examines the definitions in legislations of some countries, it is important to note that while the United Nations, World Bank and IMF cover all countries, regional bodies such as ADB, AfDB, EIB, etc. cover only countries within the spheres of their mandates. It is also in this respect that the discussion is centred mainly in selected countries with strong PPP policies and practices in North America, South America, Asia, Europe, Africa and the Middle East.

\footnotetext{
${ }^{26}$ European Bank for Reconstruction and Development, Public Private Partnerships $(P P P s)$

<https://www.ebrd.com/infrastructure/infrastructurePPPs.com>. Accessed 04 January 2020.

${ }_{27}$ Organization for Economic Cooperation and Development, Recommendation of the Council on Principles for Public Governance of Public Private Partnerships, [May, 2012] <http://www.oecd.org /governance/budgeting/PPP-Recommendation.pdf >. Accessed 04 January 2020.

${ }^{28} \mathrm{Ibid}$.

29 Asian Development Bank, Public Private Partnerships Handbook <https://www.adb.org/sites /default/files/institutionaldocument/31484/public-private-partnership.pdf >. Accessed 04 January 2020.

${ }^{30}$ Asian Development Bank, Public Private Partnership Monitor, (2017, ADB), xiii.

${ }^{31}$ African Development Bank Group, Evaluation of the Bank's Utilization of the Public Private Partnership Mechanism (2006 - 2016): Inception Report Volume 1, Main Report [03 April 2017], 9 $<$ http://idev.afdb.org/sites/default/files/documents/files/PPP-

Inception\%20Report\%20Vol\%201\%20Main \%20Report.pdf>. Accessed 04 January 2020.
}

\section{PPP Concept in Legal Instruments of National Jurisdictions}

The Canadian Council for Public Private Partnerships (CCPPP) defined PPP as 'a cooperative venture between the public and private sectors built on the expertise of each partner that best meets clearly defined public needs through the appropriate allocation of resources, risks and rewards ${ }^{32}$ In British Columbia, which is the sixth province of Canada, PPP was defined simply as a contract, rather than partnership,${ }^{33}$ between a public authority and a private entity that outlines the provision of assets and the delivery of services. ${ }^{34}$ Canada is an official founding member of OECD, which observably, gave a definition of PPP in terms of public infrastructure and sharing of risks. ${ }^{35}$

The Brazilian legal framework ${ }^{36}$ statutorily divided concessions into three categories, namely sponsored, administrative and ordinary, and only considered the first two as PPP. The statutory PPP, i.e. sponsored or administrative concession, is restricted to the provision of public services by the private sector on such terms that the government is the direct or indirect user of services and consequently, directly pays or guarantees the payments for such services. It was therefore defined as an agreement entered into between government or public sector entities that establish a legally binding obligation to establish or manage, in whole or in part, services, undertaking or activities in the public interest in which the private sector is responsible for financing, investment and management. ${ }^{37}$

In the Public Private Partnership Handbook ${ }^{38}$ issued by the Ministry of Finance of Singapore in March 2012, PPP was defined as 'a long term partnering relationships between the public and private sectors to deliver services'. The fundamental policy thrust in Singapore is for the public sector to focus on acquiring services at the most cost-effective basis, rather than directly owning and operating assets. Singapore is

\footnotetext{
${ }^{32}$ Canadian Council for Public Private Partnerships, Definitions and Models <https://www.pppcouncil.ca/web/p3_Knowledge_Centre/About_P3s/Definiti ons_Models.aspx.> Accessed 09 January 2020.

${ }^{33}$ This was the conception of Partnership BC, a private company owned by the government that was responsible for all PPPs in British Columbia. See Keith Reynolds, Public Private Partnerships in British Columbia, (Columbia Institute, 2018), 7 <https://ameqenligne.com/news_pdf/pdf_docs_201806 12070622_1_12.PDF> Accessed 09 January 2020.

${ }^{34}$ The Auditor General of British Columbia, Understanding Public Private Partnerships

[2011]

<https://www.bcauditor.com/sites/default/files/publications/2011/report2/files /oagbc-understanding-p3-public-private-partnerships.pdf> Accessed 09 January 2020.

${ }^{35}$ Organization for Economic Cooperation and Development, (n. 27).

${ }^{36}$ PPP Federal Law No. 11,079 of 2004 cited in Thiago Fernades Moreira and Thiago Luis Sombra, 'The Public Private Partnership Law Review: Brazil' in Thiago Fernades Moreira and Thiago Luis Sombra (eds), The Public Private Partnership Law Reviews, (2019) TLR, $5^{\text {th }}$ edition, 33; $<$ https://thelawreviews.co.uk/edition/the-public-private-partnership-lawreview-edition-5/1189691/ brazil> Accessed 09 January 2020.

${ }^{37}$ Ibid, Thiago Fernades Moreira and Thiago Luis Sombra (eds).

${ }^{38}$ Ministry of Finance Singapore, Public Private Partnership Handbook: Version 2 [2012] <https://www.mof.gov.sg/docs/defaultsource/policies/procurementprocess/ppphandbook2012.pdf >. Accessed 03 January 2020.
} 
a member of the Asian Development Bank, which defined PPP in terms of optimal service delivery and value for money. ${ }^{39}$

The Indian Ministry of Finance issued a guideline in which PPP was defined as a project based on a contract or concession agreement between a government entity and a private company for delivering an infrastructure or service on payment of user charges. ${ }^{40}$ Similarly, PPP under the India Infrastructure Project Development Fund is defined as a partnership between a public sector and a private sector entity, whose private ownership structure is not less than $51 \%$ equity, for the creation and management of infrastructure, for public purposes, and for a specified period of time, on commercial terms, and in which the private partner has been selected through a transparent and open procurement system. ${ }^{41}$ This definition looked at PPP from a transaction perspective. This is curious in view of its coverage under the ambit of the Asian Development Bank, which looked at PPPs mainly in terms of optimal service delivery and value for money. However, the common law roots of India must have influenced its adoption of the transaction-mode definition of PPP.

Pakistan's Public Private Partnership Authority Act $2017^{42}$ defined PPP as "a commercial transaction between an implementing agency and a private party in terms of which the private party - (i) performs an implementing agency's functions on behalf of it; (ii) assumes the use of public property for a project; (iii) assumes substantial financial, technical and operational risks in connection with performance of the implementing agency's functions or use of the public property; or (iv) receives a benefit for performing the implementing agency's or from utilizing the public property, either by way of - (A) consideration to be paid by the implementing agency from its budget or revenue; or (B) charges or fees to be collected by the private party from users or customers of a service provided to them; or (C) a combination of such consideration and such charges or fees. ${ }^{43}$

The Philippines' State Authorities (Public Private Partnership Arrangements) Act, $2002^{44}$ has made extensive provision on the definition of what it called PPP. It stated that PPP

\footnotetext{
${ }^{39}$ Asian Development Bank, (n. 30).

${ }^{40}$ Ti-UP Resource Centre, Public Private Partnerships in India (2010) 3 $<$ https://assets.publishing.

service.gov.uk/media/57a08afa40f0b649740008b6/TI_UP_HD_Aug2010_Pu

blic_Private_Partnership_in_India.pdf> Accessed 11 April 2021.

${ }^{41}$ Department of Economic Affairs, Scheme and Guidelines for India Infrastructure Project Development Fund (Government of India, 2000), 7 <http://mohua.gov.in/upload/uploadfiles/files/Guideline_Scheme_ IIPDF. pdf $>$ Accessed 11 April 2021.

42 Public Private Partnership Authority Act, No. VIII of 2017, $<$ http://www.na.gov.pk/uploads/documents /1491459302_426.pdf >. Accessed 03 January 2020.

${ }^{43}$ Ibid, Section 2(o).

${ }^{44}$ State Authorities (Public Private Partnership Arrangements) Act, 2002 (Philippines) <https://ppp.gov.ie/wp/ files/documents/legislation/state_authorities_act.pdf >. Accessed 03 January 2020.
}

arrangement has the meaning given to it under section 3(1) of the Act. ${ }^{45}$ The section provides that PPP is 'an arrangement between a state authority and a person for the performance of functions of the state authority in relation to four separate arrangements, which it listed as Design, Build, Operate and Finance (DBOF); ${ }^{46}$ Design, Build and Operate (DBO); ${ }^{47}$ Design, Build and Finance (DBF); ${ }^{48}$ and Operate and Finance a service for a minimum period of 5 years. ${ }^{49}$ This definition is very specific and restrictive.

In the UK, PPP was defined as an arrangement typified by joint working between the public and private sector to deliver policies, services and infrastructure. ${ }^{50}$ This definition is unique in view of its broadness to such an extent that it could accommodate arrangements, which in many jurisdictions are not considered as PPP, for instance, privatization. ${ }^{51}$ It needs to be mentioned that the statutory provision in the UK did not adopt PPP as a terminology. In the Concession Contracts Regulations that came into force on $18^{\text {th }}$ April 2016, ${ }^{52}$ 'concession contract' was rather used, and was defined to mean "a works concession contract or a services concession contract". ${ }^{53}$ These respective terms were further defined as contracts for pecuniary interest concluded in writing by which contracting authorities entrust the execution of works, ${ }^{54}$ or services, ${ }^{55}$ to one or more economic operators, ${ }^{56}$ and which meets the requirements stipulated therein. ${ }^{57}$ The definitions in the UK by both the HM Treasury and under the Concession Contract Regulations appeared to be a departure from both the common law transactional approach and the European Union's perspective of PPP, being essentially a transfer of governmental function to the private sector.

In the Republic of Ireland, PPPs were partnerships between the public and private sectors for the purpose of delivering a project or service traditionally provided by the public sector. ${ }^{58}$ This definition seemed to be largely influenced by the

\footnotetext{
${ }^{45}$ Ibid, Section 1(1).

${ }^{46}$ Ibid, Section 3(1)(a)(i).

${ }^{47}$ Ibid, Section 3(1)(a)(ii).

${ }^{48}$ Ibid, Section 3(1)(a)(iii).

${ }^{49}$ Ibid, Section 3(1)(a)(iv).

${ }^{50}$ Nwangwu G., Public Private Partnerships in Nigeria: Managing Risks and Identifying Opportunities (Palgrave Macmillan 2016), 14, where he referred to the relevant policy of the HM Treasury, available at http://webarchive.nationalarchives.-

gov.uk/20130129110402/http://www.hmtreasury.gov.uk/ppp_index. htm.

${ }^{51}$ Ibid, 15 .

${ }^{52}$ The Concession Contracts Regulations, No. 273 of 2016 (United Kingdom), <http://www. legislation.gov.uk/uksi/2016/273/pdfs/uksi_20160273_en.pdf> Accessed 03 January 2020.

${ }^{53}$ Ibid, section 3(1).

${ }_{55}^{54}$ Ibid, section 3(2).

${ }^{55}$ Ibid, section 3(3).

${ }^{56}$ Ibid, section 2(1) expanded the term to include temporary associations of undertaking.

${ }^{57}$ Ibid, section 3(2)(b); section 3(3)(c).

58 The Parliamentary Budget Office, An Overview of Public Private Partnerships in Ireland: Houses of the Oireachtas Briefing Paper 5 [2018], $<$ https://data.oireachtas.ie/ie/oireachtas/parliamentaryBudget office/2018/2018-03-

16_an_overview_of_public_private_partnerships_in_Ireland_en.pdf> Accessed 03 January 2020.
} 
definition of the European Commission and endorsed by the IMF that PPP involves the transfer to the private sector of investment projects that are traditionally executed or financed by the public sector. ${ }^{59}$

In South Africa, PPP was defined as a commercial transaction between an institution and a private party whereby 'the private party (a) performs an institutional functions on behalf of the institutions; (b) acquires the use of state property for its own commercial purposes; (c) assumes substantial financial, technical and operational risks in connection with the performance of the institutional function and/ or use of state property; and (d) receives a benefit for performing the institutional function or from utilizing the state property by way of: (i) consideration to be paid by the institution which derives from a revenue fund or, where the institution is a national government business enterprise or a provincial government business enterprise, from the revenues of such institution; or (ii) charges or fees to be collected by the private party from users or customers of a service provided to them; or (iii) a combination of such consideration and such charges or fees'. This definition appears to have adopted the comprehensive definition used by the African Development Bank. ${ }^{60}$

Under the National Policy on Public Private Partnership ${ }^{61}$ issued by the Government of Ghana in June 2011, PPP was defined as "a contractual arrangement between a public entity and a private sector party, with clear agreement on shared objectives for the provision of public infrastructure and services traditionally provided by the public sector." ${ }^{22}$ The National Policy further explained that in a PPP arrangement, the private sector party performs part or all of a government's service delivery functions, and assumes the associated risks for a significant period of time. In return, the private sector party receives a benefit/ financial remuneration (according to a predetermined performance criteria), which may be derived entirely from service tariffs or user charges; entirely from government budgets, which may be fixed or partially fixed, periodic payments (annuities) and contingent; or a combination of the above. ${ }^{63}$ This definition also appears, like the Indian definition, to be influenced by common law roots in looking at PPP from a transaction perspective.

\footnotetext{
${ }^{59}$ World Bank, PPP Legal Research Centre, What are Public Private Partnerships?, <https://ppp.worldbank.org/public-privatepartnership/overview/what-are-public-private-partnerships>. Accessed 03 January 2020.

${ }^{60}$ African Development Bank Group, Evaluation of the Bank's Utilization of the Public Private Partnership Mechanism (2006 - 2016): Inception Report Volume 1, Main Report [03 April 2017], 9 <http://idev.afdb.org/sites/default/files/documents/files/PPP-

Inception\%20Report\%20Vol\%201\%20Main \%20Report.pdf>. Accessed 04 January 2020.

${ }^{61}$ Government of Ghana Ministry of Finance and Economic Planning, National Policy on Public Private Partnership (PPP) [2011] $<$ https://ppp.worldbank.org/public-private-partnership/sites/ppp.worldbank. org/files/ppp_testdumb/documents/Ghana_ppp_policy.pdf>. Accessed 03 January 2020.

${ }^{62}$ Ibid, page 2 .

${ }^{63}$ Ibid.
}

The Kenyan Public Private Partnerships Act ${ }^{64}$ defined PPP as 'an arrangement between a contracting authority and a private party under which a private party undertakes to perform a public function or provide a service on behalf of the contracting authority; receives a benefit for performing a public function by way of compensation from a public fund; charges or fees collected by the private party from users or consumers of a service provided to them; or a combination of such compensation and user charges or fees; and is generally liable for risks arising from the performance of the function in accordance with the terms of the project agreement.' This definition appears to be influenced by the comprehensive definition of the AfDB.

The PPP law ${ }^{65}$ in Dubai is being governed by Law No. (22) of 2015 and titled, Regulating Partnership between the Public and the Private Sector in the Emirate of Dubai. Partnership was defined as a contractual relationship between the Public sector and the private sector, which "aims at implementing a project in whole or in part to ensure quality services; increase the revenue of a government entity or achieve any other objective through utilizing the competencies and the financial, technical, or other capabilities of the private sector." 66

At this stage, it is important to look at the definition of the concept from the academic perspective so as to understand to what extent the definitions by MDBs and countries implementing PPPs align with the definition of the concept by the academia. Delmon ${ }^{67}$ defined PPP as any contractual or legal relationship between public and private entities aimed at improving and/or expanding infrastructure services. This definition, though described as inclusive, ${ }^{68}$ is however influenced by the transactional approach like that of India and Ireland.

In the same vein of common law influence, Arimoro opted to work with the definition postulated by Kukoyi that PPP is 'a contractual arrangement between a government agency and a private sector entity that allows for greater private sector participation in the delivery of infrastructure projects' ${ }^{99}$ Engel et al, followed same trend when they defined PPP as a longterm contract between the state and a private company to

\footnotetext{
64 Public Private Partnerships Act, No. 15 of 2013, s. 2(o), <http://www.kenyalaw.org:8181/exist/

kenyalex/actview.xql?actid=NO.\%2015\%200F\%202013>. Accessed 03 January 2020.

${ }^{65}$ Regulating Partnership between the Public and the Private Sector in the Emirate of Dubai, Law No. 22 of 2015 (UAE), <https://dlp.dubai.gov.ae/Legislation\%20Reference/2015/Law\%20No.\%20(2 2)\%20of\% 202015.pdf> Accessed 03 January 2020.

${ }^{66}$ Ibid, Art. 2.

${ }^{67}$ Jeffrey Delmon, Public-Private Partnership Projects in Infrastructure: An Essential Guide for Policy Makers ( $1^{\text {st }}$ edn, Cambridge University Press 2017), 3.

${ }^{68}$ Ibid, 3

${ }^{69}$ Augustine Edobor Arimoro, The Legal Framework For Public Private Partnerships In Nigeria: Lessons Learnt So Far (Lap Lambert Academic Publishers 2015), 24.
} 
provide infrastructure. ${ }^{70}$ The definitions of these writers are largely influenced by the common law approach.

It is clear from the above definitions that the legal parameters of PPP could be restrictive or expansive. In Canada, for example, an arrangement must satisfy two conditions to be called a PPP, namely provision of public infrastructure and the transfer of risks between partners. ${ }^{71}$ There are however some countries where the definition is more expansive as to include privatization like in the UK or more restrictive as to exclude concessions or other arrangements like Philippines or more regulated as in Brazil where the public authority directly pays or guarantees the payments for such services.

On a careful analysis of the different perspectives of the PPP concept as advanced by MDBs, national jurisdictions and academic writers highlighted above, it is obvious that the PPP legal concept has the following parameters as irreducible minimum:

1. PPP is generally a contractual arrangement between a public authority and a private sector entity. The description of the concept as 'cooperation' by the African Development Bank or 'cooperative venture' by the Canadian Council for PPP or 'joint working arrangement' in United Kingdom or 'a commercial transaction' by South Africa and Pakistan cannot derogate from its main feature as a legally binding contract. The UNCITRAL's description of PPP as 'a binding agreement' is apt for countries with weak Rule of Law regimes.

2. PPP involves provision of public infrastructure and services on the basis of optimal service delivery and value for money. This was highlighted in the respective guidelines and legal framework of Asia Development Bank and Singapore. Such value for money involves utilizing competencies and the financial, technical or other capabilities of the private sector as expressly stipulated in the Dubai legal instrument.

3. Except in the EIB, IMF and the UNCITRAL legal guidelines that talked about the abidingness of contractual terms and conditions, all the MDBs put the allocation or sharing of risks, resources and rewards as a critical parameter of the concept.

4. PPP also involves a transfer of public function to the private sector as could be seen in the respective guidelines and legal instruments of IMF, Republic of Ireland, Ghana, Kenya and Philippines.

5. The compensation element is an important parameter of the PPP concept, which is also expressly linked to performance. The World Bank, Africa Development Bank, South Africa, Kenya and Pakistan are very

\footnotetext{
${ }^{70}$ E Engel and R D Fischer and A Galetovic, The Economics of PublicPrivate Partnerships: A Basic Guide (Cambridge University Press 2014), 1.

${ }^{71}$ Canada Council for Private Partnerships, (n. 32)
}

specific on compensation in their respective guidelines and legal instruments.

\section{CONCLUSION AND RECOMMENDATION}

From the definitions and analyses above, it is axiomatic that any legal definition of PPP should accommodate the above five parameters if it is to be adequate, predictable and in line with recommended guidelines. The definition of 'concession' under the ICRC Act meets only two parameters, namely the contractual arrangement on one hand and the delivery, financing and management of a public asset on the other. It is silent on other key parameters like the sharing of risks, transfer of functions to the private sector and the compensation element in the transaction. It also lacks the exactitude of the Philippines, which opted to restrict the PPP concept in terms of contractual model and minimum duration or the South African and Pakistan models, which are very specific on the role of a private partner.

Be that as it may, the definitions of PPP in many common law or other jurisdictions including those that adopted concession as the dominant or exclusive nomenclature have same parameters of 'what is' and 'what is not' a PPP. From the general parameters in the definitions of selected national jurisdictions, MDBs and academic writers, it can be appreciated that PPPs are long-term contracts for private sector participation in public infrastructure and services based on shared risks, resources and rewards. It is therefore recommended that the definition of PPP under section 36 and the obligation for maintenance and repairs under section $7(2)$ (b) of the ICRC Act should be amended to be more expansive as to accommodate the different types, classifications and parameters of PPP as propounded in the guidelines of many MDBs.

It is gratifying however that the Infrastructure Concession Regulatory Commission has not rested on its oars. It has presently proposed an amendment of the ICRC Act, ${ }^{72}$ which could see to the reinvigoration of the PPP process. The amendment hopes to, among other things, achieve a more allencompassing definition of PPP, clarification on the supervisory role of the ICRC and the capacity of MDAs to initiate, develop and implement projects. ${ }^{73}$ If this is done, the PPP concept in Nigeria will inch towards a better and more standard legal perspective.

\section{BIBLIOGRAPHY}

[1] Adeyemo D. O. and Salami A., 'A Review of Privatization and Public Enterprises Reform in Nigeria', Contemporary Management Research Journal, [2008](12)(4) 409.

[2] African Development Bank Group, Evaluation of the Bank's Utilization of the Public Private Partnership Mechanism (2006 2016): Inception Report Volume 1, Main Report [03 April 2017] $<$ http://idev.afdb.org/sites/default/files/documents /files/PPP-

\footnotetext{
${ }^{72}$ Cap. 125A, LFN 2004.

${ }^{73}$ F. Onuobia and O. J. Okoro, 'Nigeria', in Wereck B. and Saadi M. (eds), Public Private Partnership Law Review (4 ${ }^{\text {th }}$ Ed., Tom Barnes 2018), 179 <https://www.gelias.com/Newsletter_April\%202018.pdf〉. Accessed 04 October 2019.
} 
Inception\%20Report\%20Vol\%201\%20Main \%20Report.pdf> Accessed 04 March 2021.

[3] Arimoro A. E., The Legal Framework For Public Private Partnerships In Nigeria: Lessons Learnt So Far (Lap Lambert Academic Publishers, 2015).

[4] Arimoro A. E., Legal Framework For PPP: South Africa and Nigeria in Focus, $<$ https://www.researchgate.net/publication/331547104_The_Legal _framework_for_public-

private_partnership_South_Africa_and_Nigeria_in_focus> Accessed 04 March 2021

[5] Asian Development Bank, Public Private Partnerships Handbook $<$ https://www.adb.org/sites /default/files/institutionaldocument/31484/public-private-partnership.pdf $>$ Accessed 24 March 2021.

[6] Asian Development Bank, Public Private Partnership Monitor (Asian Development Bank 2017)

[7] Bao F. (et. al), Review of Public Private Partnership Literature from a Project Lifecycle Perspective (2018) $<$ https://www.researchgate.net/profile/Fengyu

Bao/publication/322929679_-

_A_Review_of_Public_Private_Partnership

_Literature_A_Project-Life_Cycle_Perspective/links/> Accessed 04 March 2021.

[8] Canadian Council for Public Private Partnerships, Definitions and Models

<https://www.pppcouncil.ca/web/p3_Knowledge_Centre/About_P 3s/Definitions_Models.aspx.> Accessed 09 March 2021.

[9] Chandra P., Projects: Planning, Analysis, Selection, Financing, Implementation, and Review, ( $7^{\text {th }}$ Edition, Tata McGraw-Hill, 2011).

[10] Delmon J., Making PPPs Work: Going to the Chapel, World Bank, http://blogs.worldbank.org/ppps/making-ppps-work-going-chapel> Accessed 10 March 2021.

[11] Delmon J., Public-Private Partnership Projects in Infrastructure: An Essential Guide for Policy Makers ( $1^{\text {st }}$ edn, Cambridge University Press 2017).

[12] Delmon J., 'Understanding Options for Public-Private Partnerships in Infrastructure: Sorting out the Forest from the Trees: BOT, DBFO, DCMF, Concession, Lease...' [2010], The World Bankisep? <https://openknowledge. worldbank.org/handle/10986/19947> Accessed 10 March 2021.

[13] Deloitte, Public Private Partnership (PPP) as an Anchor For Diversifying The Nigerian Economy: Lagos Container Terminals Concession as Case Study (March 2017), <https://www2.deloitte.com/content/dam/Deloitte/ng/ Documents/strategy/ng-PPP-as-an-anchor-for-diversifying-theNigerian-economy22032017.pgf> Accessed 09 March 2021.

[14] Department of Economic Affairs, Scheme and Guidelines for India Infrastructure Project Development Fund (Government of India, 2000) <http://mohua.gov.in/upload /uploadfiles/files/Guideline_Scheme_ IIPDF.pdf> Accessed 02 April 2021.

[15] Engel E. and Fischer R. D. and Galetovic A, The Economics of Public-Private Partnerships: A Basic Guide (Cambridge University Press 2014).

[16] European Bank for Reconstruction and Development, Public Private Partnerships (PPPS) <https://www.ebrd.com/infrastructure/infrastructurePPPs.com> Accessed 24 March 2021.

[17] European Bank for Reconstruction and Development, The EBRD Core Principles for a Modern Concession Law: Selection and Justification of Principles <https://ppp.worldbank.org/publicprivate-partnership/sites/ppp.worldbank.org/ files/documents/Core\%20Principles\%20for\%20Modern\%20Conce ssion\%20Law_EN.pdf >. Accessed 24 January 2021.

[18] Farlam P., Assessing Public Private Partnerships in Africa, Nepad Policy Focus Series 2 (South African Institute of International Affairs, 2005).

[19] Government of Ghana Ministry of Finance and Economic Planning, National Policy on Public Private Partnership (PPP)
[2011] <https://ppp.worldbank.org/public-privatepartnership/sites/ppp.worldbank.org/files/ppp_testdumb/document s/Ghana_ppp_policy.pdf> Accessed 03 March 2021.

[20] Infrastructure Concession Regulatory Commission, History (2020) <https://www.icrc.gov.ng/about-icrc/> Accessed $11^{\text {th }}$ March 2021.

[21] International Monetary Fund, Public Private Partnerships [2004] < https://www.imf.org/external/np/ fad/2004/pifp/eng/031204.pdf $>$. Accessed 14 March 2021.

[22] Leitao J. and Sarmento E. M. and Aleluia J., The Handbook on Pubic-Private Partnerships in Developing and Emerging Economies: Perspectives of Public Policy, Entrepreneurship and Poverty (Emerald Publishing Limited, 2018) <https://www.academia.edu/36179545/The_Emerald_Handbook of_Public_Private

_Partnerships_in_Developing_and_Emerging_Economies_Perspec tives_on_Public_Policy_Entrepreneurship_and_Poverty> Accessed 6 March 2021.

[23] Ministry of Finance Singapore, Public Private Partnership Handbook: $\quad$ Version 2012$]$ <https://www.mof.gov.sg/docs/default-

source/policies/procurement process/ppphandbook2012.pdf> Accessed 03 March 2021.

[24] Moreira T. F. and Sombra T. L., 'The Public Private Partnership Law Review: Brazil' in Moreira T. F. and Sombra T. L. (eds), The Public Private Partnership Law Reviews, (TLR, $5^{\text {th }}$ edition, 2019) $<$ https://thelawreviews.co.uk/edition/the-public-privatepartnership-law-review-edition-5/1189691/ brazil> Accessed 09 March 2021.

[25] Nwangwu G., Public Private Partnerships in Nigeria: Managing Risks and Identifying Opportunities (Palgrave Macmillan 2016).

[26] Organization for Economic Cooperation and Development, Recommendation of the Council on Principles for Public Governance of Public Private Partnerships [May, 2012] $<$ http://www.oecd.org /governance/budgeting/PPPRecommendation.pdf $>$. Accessed 04 April 2021.

[27] Onuobia F. and Okoro O. J, 'Nigeria', in Wereck B. and Saadi M. (eds), Public Private Partnership Law Review (4 ${ }^{\text {th }}$ Ed., Tom Barnes 2018),

〈https://www.gelias.com/Newsletter_April\%202018.pdf> Accessed 04 March 2021.

[28] Peterson G. E., Unlocking Land Values to Finance Urban Infrastructure (The World Bank, 2009).

[29] PPP Legal Research Centre, World Bank, What are Public Private Partnerships? <https://ppp.worldbank.org/public-privatepartnership/overview/what-are-public-private-partnerships> Accessed 03 March 2021.

[30] Reynolds K., Public Private Partnerships in British Columbia, (Columbia Institute, 2018) $<$ https://ameqenligne.com/news_pdf/pdf_docs_20180612070622 1_12.PDF> Accessed 09 March 2021.

[31] Secretary to the Government of the Federation, 'Administration of Concession Programme of the Federal Government of Nigeria', Circular Ref. No. SGF.50/S.37/II/749 (Abuja, 14 ${ }^{\text {th }}$ September 2020).

[32] The Auditor General of British Columbia, Understanding Public Private Partnerships [2011] <https://www.bcauditor.com/sites/default/files/publications/2011/r eport2/ files/oagbc-understanding-p3-public-privatepartnerships.pdf> Accessed 09 March 2021.

[33] The European Commission, A Guide to the Statistical Treatment of PPPs [2016] <https://ec.europa. eu/eurostat/documents/1015035/7204121/epec-eurostat-statistical -guide-en.pdf $>$. Accessed 04 April 2021

[34] The Parliamentary Budget Office, An Overview of Public Private Partnerships in Ireland: Houses of the Oireachtas Briefing Paper <https://data.oireachtas.ie/ie/oireachtas/parliamentaryBudget office/2018/2018-03-

16_an_overview_of_public_private_partnerships_in_Ireland_en.p df > Accessed 03 April 2021. 
[35] Ti-UP Resource Centre, Public Private Partnerships in India (2010) $<$ https://assets.publishing. service.gov.uk/media/57a08afa40f0b649740008b6/TI_UP _HD_Aug2010_Public_Private_Partnership_in_India.pdf> Accessed 11 April 2021.

[36] UNCITRAL, Model Legislative Provisions on Privately Funded Infrastructure Projects <https://www.uncitral.org/pdf/english/texts/procurem/pfip/model/ 03-90621_Ebook.pdf>. Accessed 02 April 2020.

[37] World Bank, PPP Legal Research Centre, What are Public Private Partnerships? <https://ppp.worldbank.org/public-privatepartnership/overview/what-are-public-private-partnerships>. Accessed 03 March 2021.
[38] Yescombe E. R., Public Private Partnerships In Sub-Saharan Africa - Case Studies For Policy Makers, (Mkuki na Nyota publishers for Uongozi Institute, 2017);

[39] Zverev A., The Legal Framework For Public Private Partnerships (PPPs) and Concessions in Transition Countries: Evolution and Trends, Global Infrastructure Hub <https://www.ebrd.com/ downloads/news/lit112a.pdf $>$.Edward RA Yescombe, Public Private Partnerships In Sub-Saharan Africa - Case Studies For Policy Makers, (Mkuki na Nyota publishers for Uongozi Institute, 2017), p. 23; <https://www.africaportal.org/publications/publicprivat-partnerships-sub-saharan-africa-case-studies-policymakers2007/> accessed on 23 March 2021. 